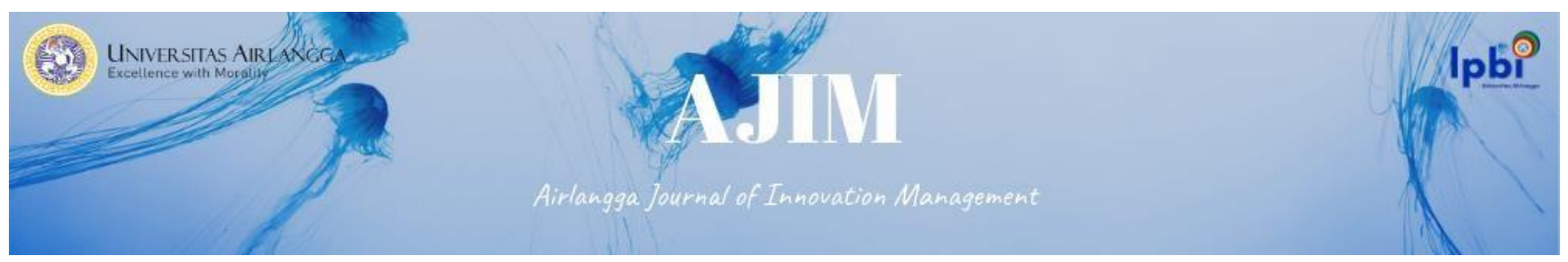

Vol. 2 No.2 Oktober 2021

e-ISSN: 2722-5062

DOI : 10.20473/ajim.v\%vi\%i.27332

\title{
THE ROLE OF INSURANCE IN ANTICIPATING THE RISK OF DEFAULT IN PEER TO PEER (P2P) LENDING SCHEME
}

\author{
Ida Ayu Rhadana Satvikarani M**, Mas Rahmah ${ }^{\mathrm{b}}$, Dian Purnama Anugerah \\ ${ }^{\mathrm{a}, \mathrm{b}, \mathrm{c}}$ Faculty of Law, Universitas Airlangga \\ *Corresponding email: ida.ayu.rhadana-2018@fh.unair.ac.id
}

\begin{abstract}
The presence of fintech in Indonesia is said as an answer of people needs about the ease on transaction and financing in business activity. According to Article 3 of POJK No.77 of 2016 concerning Information Technology-Based Money Lending Services, it is explained that Information Technologybased Money Lending Service is the implementation of financial services to bring lenders together with borrowers in order to make loan agreements in rupiah currency directly through electronic systems using internet networks commonly referred to as Peer to Peer (P2P) Lending. Commonly when the default in $\mathrm{P} 2 \mathrm{P}$ Lending exist, the role of insurance is to mitigate the risk in order to support lender protection. This study reviewed the risk of default in $\mathrm{P} 2 \mathrm{P}$ lending schemes, within discussion of insurance role in doing mitigation of default risk in P2P lending. This legal research uses normative juridical research method with statute approach and conceptual approach. The study result explain that P2P Lending is a form of investment, in which every investment must have a risk, and this risk is directly proportional to the high risk high return. Default or often referred to as non-performing loan (NPL) is a situation where borrowers are late to return principal of the loan more than 90 days from maturity time, therefore risk mitigation is important. The purpose of insurance scheme in P2P Lending fintech services is an effort to overcome losses suffered by lenders.
\end{abstract}

Keywords : Insurance, Default Risk, Peer to Peer Lending

\section{Introduction.}

The financial services industry has experienced significant innovation in line with the rapid development of digital technology today. Financial service innovation that has been influenced by technological developments and is currently a hot topic of discussion is financial technology (fintech). Fintech itself can be described as an industry consist of companies using new technologies and innovations with available resources to compete in market of financial institutions and intermediaries in delivery of financial services (Anugrah and Indriani: 2018). Each fintech company has a different focus such as; Payments, Lending, Personal Finance, Retail Investment, Crowdfunding, Remittance and Financial Research. Crowdfunding itself is further grouped into 4 characteristics of business, including, Consumer Lending or Lending-based, Donation-based, Reward-based and Equity-based.

The Fintech concept adapts technological developments that are combined with financial sector in banking institutions, so that it is expected to facilitate more practical, safe and modern financial 


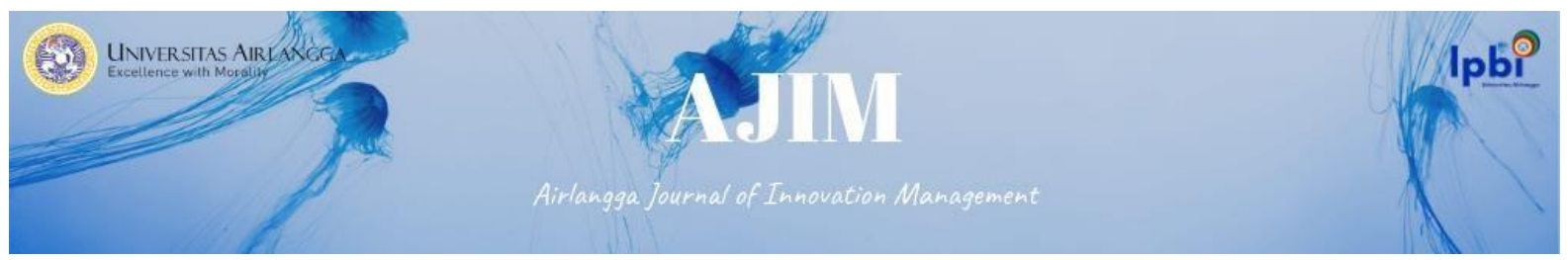

transaction processes. The existence of fintech in Indonesia is increasingly spreading and is expected to continue to grow in current industrial era 4.0, not just the use of internet access but also technological innovation that guides everything to change quickly and dynamically. So this is why fintech becomes implementation and use of technology to improve banking and financial services which are generally carried out by startup companies by utilizing latest software, internet, and computerization technology (Iman: 2006).

Based development of fintech lending issued by Indonesia Financial Service Board (OJK:2019), data as of January 22, 2020, there are 164 companies registered with the OJK and only 25 companies are licensed.This shows that P2P Lending is developing very rapidly in Indonesia. OJK noted that most fintech lending disburses loans on Java. The largest was in DKI Jakarta, amounting to Rp. 25.09 trillion. Furthermore, West Java Rp 22.05 trillion, East Java Rp 8.89 trillion, Banten Rp 7.59 trillion, and Central Java Rp 5.29 trillion. There are still many P2P Lending fintech companies that have not been registered, causing many risks of violations of P2P Lending platform outside OJK supervision, because OJK itself is only entitled to supervise P2P Lending fintechs that already have a permit so that the legal impact on perpetrators/ illegal companies fintech is not OJK responsibility, for that investors must be more careful in choosing fintech companies.

Based on OJK data, in 2019 loans disbursed by fintech P2P Lending have reached IDR 81.5 trillion. This figure increased by $259.56 \%$ from the previous year. Even as of December, outstanding P2P Lending fintech loans reached Rp 13.16 trillion. Compared with disbursement of loans from Commercial Banks for Business Activities (BUKU) I, which until November 2019 had only reached Rp 36.64 trillion. This figure fell 17.07\% compared to the beginning of 2019 of Rp 46.6 trillion. So it can be concluded that now number of loans disbursed by fintech lending is greater than small banks. The number of accounts of lenders and borrowers also increased rapidly. The number of lender accounts increased by $192.01 \%$ to 605,935 accounts and the number of borrower accounts increased by $325.95 \%$ to 18.57 million accounts (Franedya:2020).

Like other conventional lending and borrowing agreements in fintech, especially P2P Lending, are not free from risks. The biggest risk when investing is failure to pay or often called default. The term default is known and used in the financial world to describe a situation where a borrower cannot fulfill his obligations in accordance with the debt agreement they made, resulting in arrears of debt from borrower, lender must ready for risk of losing their funds because in POJK all forms of default or other risks are delegated to platform organizers themselves, so there is no strong legal standing in the event of default/failure to pay the lenders. In terms of success rate of paying P2P Lending platform for 90 days (TKB90) it is in range of $96.35 \%$. This means that $3.65 \%$ of loans or equivalent of Rp. 48.03 billion have failed to pay. Factors causing default, among others, are causes of bad loans, including failure of borrower's business, calamity of borrower or borrower's business activities as well as the decline in economic activity and high credit interest rates (Gogo: 2020). One of trusted P2P platforms in Indonesia, Investree mitigate their risk by conduct analysis, selection, and approval based on a modern credit-scoring system for each loan submitted. After lender's funds are disbursed to borrower, Investree will also carry out supervision to ensure that there is no misuse of funds provided, so that repayments can be made on time (Investree: 2020).

P2P Lending arrangements in Indonesia have not been able to accommodate legal protection for parties related to P2P Lending. This will bring into material rights in debt agreement and absence of standards regarding what risk mitigation must be applied in each P2P Lending platform as well as application of insurance schemes as risk mitigation in default of debt agreement.Insurance acts as a part of risk mitigation could support lenders' protection, where insurance companies enter into cooperation 


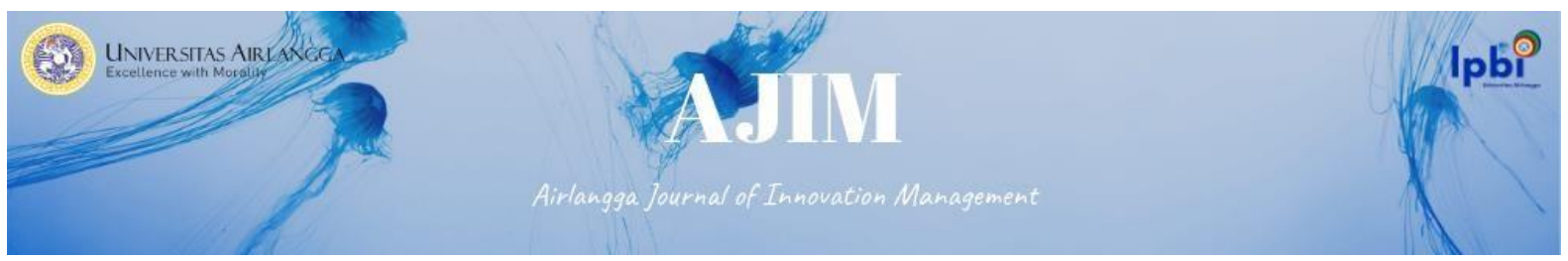

agreements with relevant P2P Lending platform and then lenders pay premiums through P2P Lending platform. Then insurance company will pay remaining debt of borrower to lender so that it can at least cover up to $70 \%$ even $100 \%$ of remaining receivables depending on provisions of each insurance company and agreement previously agreed. The discussion above raises a legal issue related to obligations of P2P Lending providers in carry out risk mitigation, which is not clearly explained in POJK No. 77/POJK.01/2016 as risk mitigation is most important element in protection of lenders as parties who carry risk of non-fulfillment of borrower obligations to lenders resulting in losses to lenders and importance of the role of insurance as part of risk mitigation in P2P Lending services.

Based on description above, this research will focus on legal discussion of risk of default in $\mathrm{P} 2 \mathrm{P}$ lending schemes and the role of insurance as a risk mitigation instrument against default in $\mathrm{P} 2 \mathrm{P}$ lending.

\section{Literature Review}

\section{Fintech}

According to The National Digital Research Center (NDRC), fintech is a financial information technology whose term is used to refer to an innovation in the field of financial services, where the term comes from the words "financial" and "technology" which refers to financial innovation with a touch of modern technology or innovation in financial services. Fintech is result of a combination of financial services and technology that ultimately changes business model from conventional to moderate, which initially has to pay face-to-face and carry a certain amount of cash, can now carry out long-distance transactions by making payments that can be made in just seconds (BI: 2020).

\section{P2P Lending}

In 2016, OJK issued a regulatory policy regarding fintech, namely Peraturan OJK No.77/POJK.01/2016 concerning Information Technology-Based Lending and Borrowing Services. OJK also makes Fintech as a matter in spotlight and requires a clear legal umbrella in its regulation. Based on this regulation, P2P Lending is defined as follows:

"Information Technology-Based Borrowing and Borrowing Services is a financial service provider to bring together lenders and loan recipients in order to enter into lending and borrowing agreements in rupiah currency directly through an electronic system using the internet network."

P2P Lending is included in the category of Crowdfunding Basis Loans (Consumer Lending or Lending-based). Currently there are many companies engaged in P2P Lending, these companies carry out their activities by creating a site or application (platform) that functions as a meeting place for lenders and borrowers, P2P Lending does not require collateral for loan funds provided. P2P lending investments offer an attractive rate of return (Mentari: 2020). Profits or returns for lenders who place funds on the P2P Lending platform reach $18 \%$ to $20 \%$ per year, higher than the current average annual increase in property prices and competing with investment benefits of Equity Mutual Funds (Quiserto:2019). The following is the process scheme for the occurrence of P2P Lending fintech-based investments:

Figure 1.1: P2P Lending Cycle 

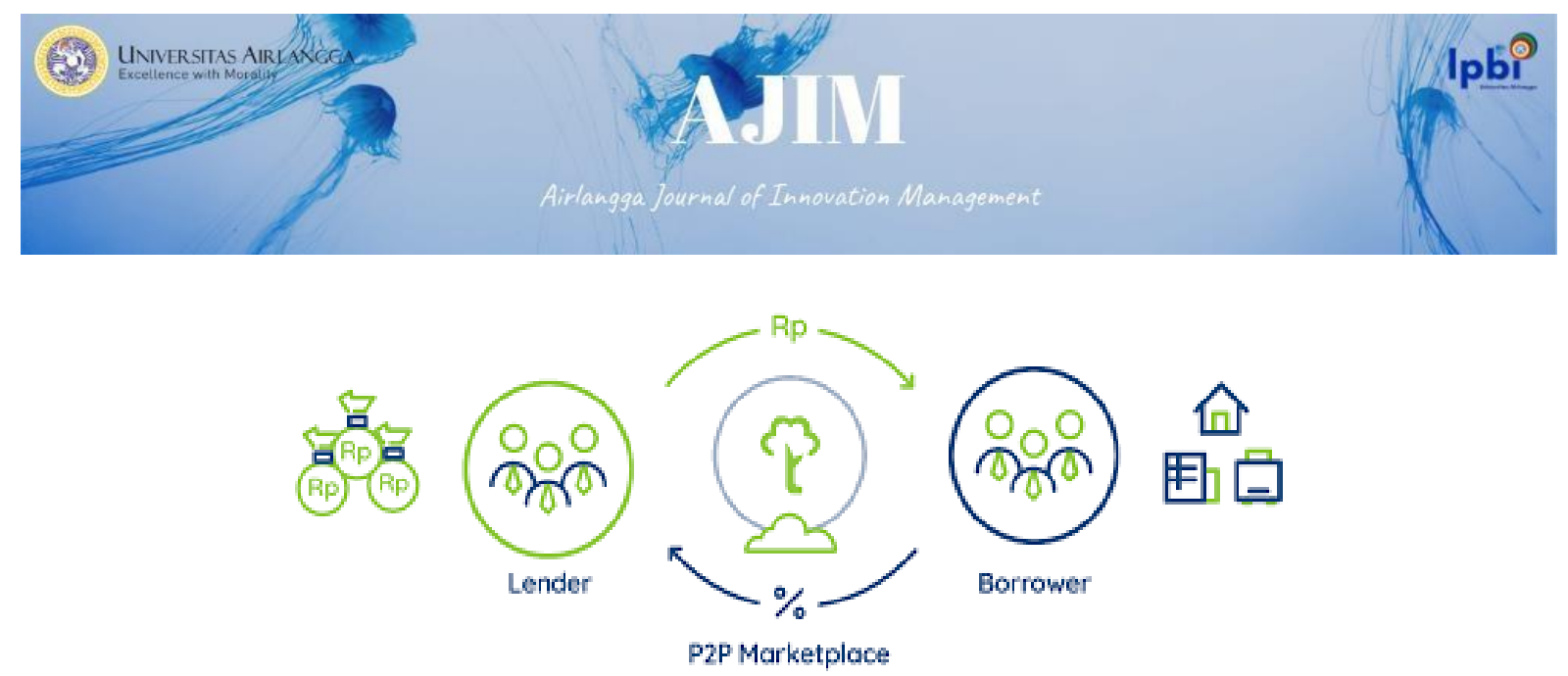

Source : $\underline{w w w . i n v e s t r e e . i d}$

\section{Risk / Default}

The term default or default is known and used in the financial world to describe a situation where a debtor is unable to fulfill his obligations in accordance with the credit agreement he made, for example not making installment payments or paying off the principal debt in accordance with the agreement, including violating the credit terms as regulated in in the contract. This condition can occur in all debt obligations, including in the P2P Lending scheme.

Failure to pay is a form of default of an agreement. The default itself is influenced by factors such as the risk of bankruptcy caused by unexpected conditions that cannot be avoided by any company, such as a recession or economic crisis. Although P2P Lending debt scheme has an online basis, there is no guarantee that the scheme will survive in the event of a recession or economic crisis. Under these conditions, it is estimated that the incidence of default or default will increase and cause a decrease in the lender's rate of return, both principal and interest loans.

So apart from all the positive values and benefits of P2P Lending fintech, there are also many other risks in the development of financial technology in Indonesia, such as the potential for loss or decline in financial capacity, whether caused by abuse, fraud or force majeure. Because in its implementation, for now the functions of the OJK are only technical and administrative sanctions and license revocations are not yet focused on legal protection of lenders, the legal protection in POJK Number. This can minimize losses by mitigating risks.

\section{Methods / Materials}

In connection with the type of research used in this research is normative juridical, then approach taken is statutory approach and conceptual approach. The statute approach is carried out by reviewing all laws and regulations related to the legal issues being handled. This approach is carried out by reviewing, analyzing, and emphasizing the search for norms contained in legislation (Marzuki: 2017). The statutory approach referred to in this study is to examine and describe the legal rules relating to the implementation of online lending and borrowing services (peer to peer lending). The conceptual approach departs from views and doctrines that develop in science of law. The research was carried out based on views and doctrines in legal science to then find ideas that gave birth to legal understanding, legal concepts, and legal principles that are relevant to the legal issues (Marzuki: 2017) encountered in this study and then used in building a legal argument. in solving the legal issues of this research. 


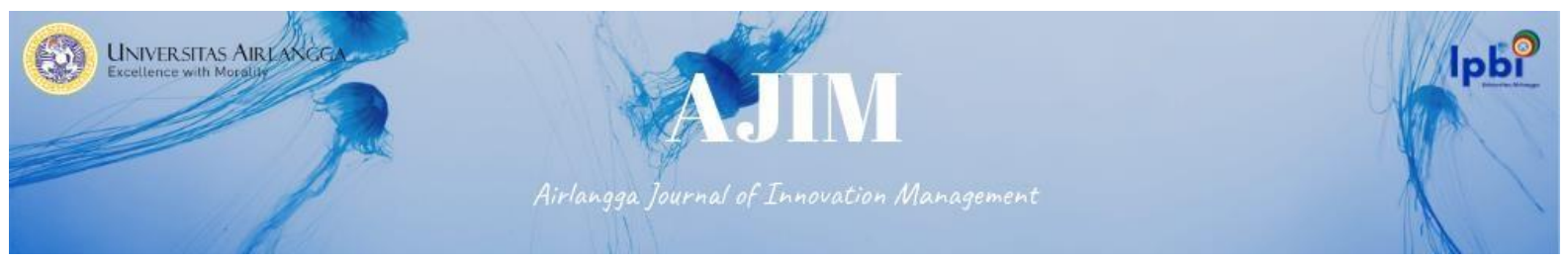

\section{Results and Discussion}

\section{Risk of Default in Peer to Peer Lending Scheme.}

In financing business industry, both banking and non-banking, basically there is a risk of loss, including financing institutions with P2P Lending schemes, where one of most common forms of default is default by borrowers. In P2P Lending scheme, if borrower fails to pay, it can also be referred to as default, namely a state of non-performance due to debtor's fault, in this case borrower, either intentionally or by negligence. Based on article $1234 \mathrm{BW}$, it is stated that engagement object can be in form of giving something, doing something, or not doing something. Therefore, if one of parties does not perform in an engagement, then that party can be said to be defective or in breach of contract. In investing, of course, there is such a thing as risk which is directly proportional to returns obtained. All types of investments, from mutual funds to stocks, have risks, although with different types of risk. There is also a risk in P2P Lending funding, where the biggest risk is the risk of non-performing loan or NPL default). Default or NPL is a situation where the borrower is late in returning the loan principal for more than 90 days (Madian: 2020).

Figure 2.2 Percentage of TKB90)

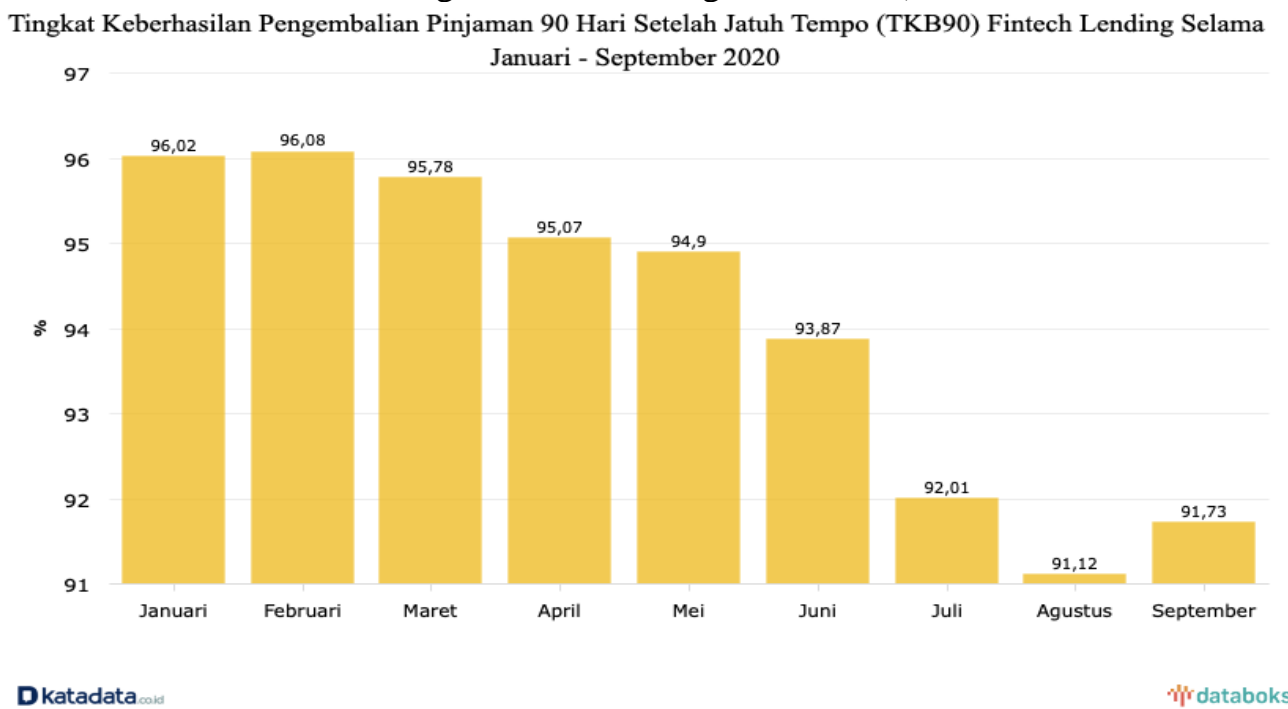

Source: https://databoks.katadata.co.id/

The success rate of 90 ( TKB90) is a term commonly used in world of P2P Lending. Even term TKB90 itself can be used by prospective lenders as one of considerations for investing loan funds in a $\mathrm{P} 2 \mathrm{P}$ Lending company. TKB90 refers to a measure of success rate of $\mathrm{P} 2 \mathrm{P}$ Lending providers in providing loan and borrowing obligation settlement facilities within 90 days from maturity date.

OJK recorded the success rate of loan repayments a maximum of 90 days after maturity or TKB90 fintech lending increased as of September 2020 which was $91.73 \%$. Previously, from February to August TKB value continued to decline. As of February 2020 TKB90 is $96.08 \%$. Then, the last data recorded as of August 2020, TKB90 was $91.12 \%$. The decrease in TKB90 indicates that ratio of non-performing loans (NPL) is also increasing. NPL in February 2020 was 3.92\%, then in August 2020 it was 8.88\%. However, in September 2020 the NPL decreased to 8.27\% (Annur:2020).

The cause of decline in TKB90 is closely related to condition of Covid-19 pandemic that is currently engulfing world community, including Indonesia, based on data compiled by Worldometers, Indonesia ranks 19th out of total number of confirmed positive cases of Covid-19 in world, so based on graphic data Non-Performing Loans (NPLs) which are attached above, a person's success rate in writing debt/loans decreases so that NPL percentage rating also increases. Pandemic has impacted quality of 


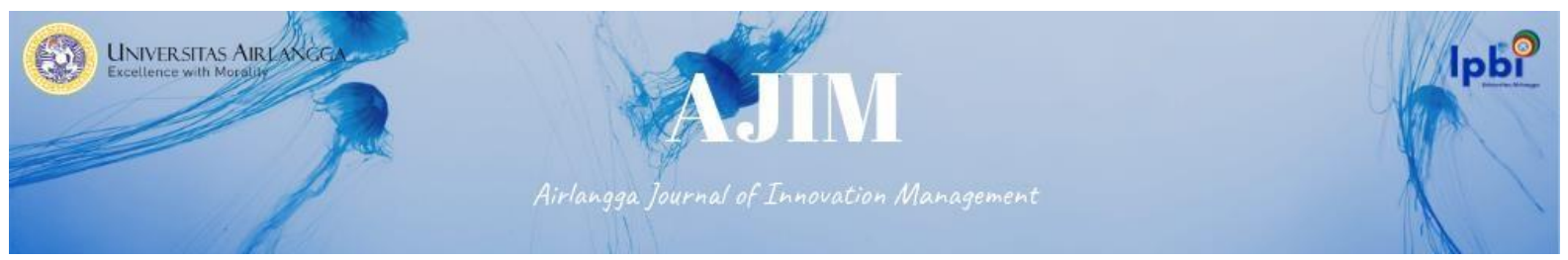

P2P Lending fintech loans throughout 2020. Based on data from OJK, loan default rate (TWP) is above 90 days at the level of $7.58 \%$ as of October 2020. This value has increased when compared to the October 2019 period which was is at the level of $2.84 \%$ (Walfajri:2020)

Therefore, it can be concluded that risk of default in P2P Lending scheme can be caused by:

a. Overmarcht in form of an unexpected natural disaster that paralyzes economic activity in a certain area. In legal dictionary Overmacht has meaning of coercive circumstances, namely conditions that prevent fulfillment of an engagement that frees a person from obligation to reimburse costs, losses and interest. In French it is called Force Majeure which means same as a state of coercion (Hamzah: 1986). Articles 1244 and 1245 BW are legal basis for Overmacht's legal basis which frees debtor from obligation to fulfill (nakoming) and compensate (schadevergoeding) even though debtor has committed an unlawful act.

b. An economic recession/crisis that causes financial difficulties for borrowers. Although P2P Lending scheme has an online basis and has been running for more than a decade, there is no guarantee that scheme will survive in economic crisis. Under these conditions, it is estimated that incidence of default will increase and cause a decrease in lender's rate of return, both principal and interest loans.

c. The borrower's business goes bankrupt, because payments depend on borrower's business so that borrower loses his income.

d. Cyber crime is a condition where Borrower is not owner of real identity so that there is a possibility that no payment will be made at all. Borrowers may be victims of identity theft or individuals who falsify salary information and debt obligations that could affect their ability to pay.

e. P2P Lending companies experience bankruptcy, risk of bankruptcy caused by unexpected conditions which cannot be avoided by any company.

The absence of collateral in P2P Lending puts the lender in a position that has a higher risk if the borrower fails to pay (Bahsan: 2017). In fact, good lender protection will also increase lenders' interest in providing loans so that it will provide easier credit accessibility to the community because the supply of credit is increasing. On the other hand, it is important to understand that fundamentally, the lenders fully bear the risk of bad loans. This is different from the bank credit system, which basically puts the risk of bad credit on the bank as the lender. The biggest risk that must be borne by lenders in P2P Lending is if there is a bad loan (default) by the borrower (Darman: 2019). P2P Lending investment risks are not small, but that doesn't mean they can't be managed.

The main purpose of insurance is to transfer the insured's risk to the insurer which means that the insurer is obliged to replace the insured's loss in the event of an event. Minimize the risk that must be faced by the insured in the event of an event that is detrimental to the insured. The loss insurer will accept the transfer or transfer of risk from the insured by being able to show evidence of experiencing a loss. Guided by the principles of insurance agreements in general, it is explained that (Chumaida: 2020).

a. Principle of Insurable Interest

b. Indemnity Principle (Principle of Indemnity)

c. Principles of Good Faith (Utmost Good Faith)

d. Principle of Subrogation (Subrogation)

It is important to note that risk mitigation in the form of insurance protection is not required or mandated in government regulations so that the cooperation between the organizer and the insurance company can change at any time. The claim fund prepared by the insurance company also has a limit (ceiling) in the event of a significant additional default. Similar to a bank that has a Deposit Insurance Corporation (LPS) as an independent institution that functions to guarantee the deposits of banking customers in Indonesia by setting and collecting guarantee premiums, the P2P Lending platform should also implement an insurance scheme as a guarantor of lenders' loan funds so that they do not fully suffer 


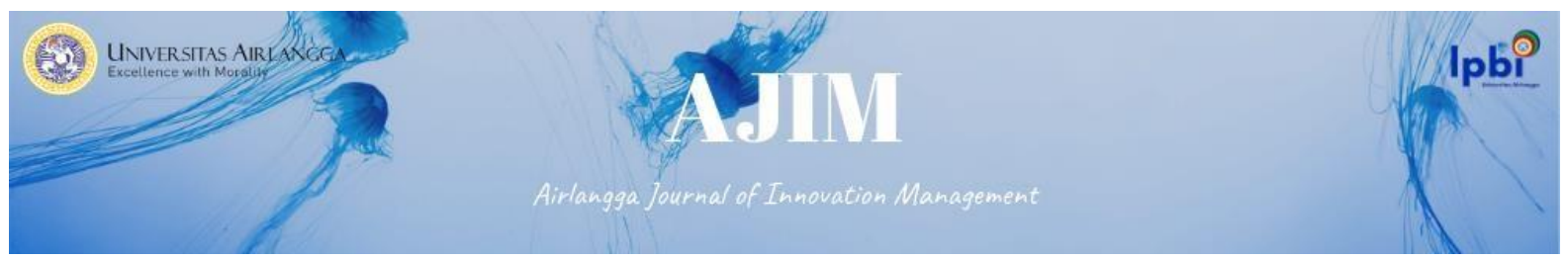

losses. in the event of a default (Cermati: 2020). Insurance companies that have collaborated with P2P Lending companies include credit insurance companies Qoala, Simasnet, Marsh, Asei, etc.

Lenders are parties who have the potential to have risks and also those who pay premiums are referred to as the "insured" and the insurance company is the party who accepts/treats the risk which is then referred to as the "insurer". The object of coverage in P2P Lending insurance is the risk of loss experienced by the lender due to bad credit from the borrower, resulting in the right to collect.

New credit insurance claims can begin to be processed when the loan has entered the default category, which is bad for more than 90 days. On the 91 st day, the new operator will process the claim to the insurance, and this process can take up to 90 days. So, lenders need to wait up to 180 days to receive compensation from the insurance company, and the compensation covered by insurance is not fully covered. In more detail, the insurance scheme in P2P Lending can be explained as follows:

1. The lender agrees to use insurance protection/financing guarantor through the P2P Lending platform as risk mitigation in the event of default by the borrower. However, in this case the lender is given the freedom whether to use insurance services or not.

2. If the lender agrees to participate in the fund protection program using an insurance scheme, the lender hereby agrees to pay the costs incurred for the financing guarantee by the insurance company determined by the P2P Lending operator, in accordance with the power of attorney for receiving funds from the lender to the third party. the provider and the loan distribution services agreement so that here the position of the $\mathrm{P} 2 \mathrm{P}$ Lending operator changes to that of the guarantor and the position of the lender becomes the insured.

3. Payment of premium fees charged to lenders is in accordance with the percentage of total funds lent by lenders and is also in accordance with the initial agreement between the insurance company and the P2P Lending company itself. The lender is the owner of the risk where the risk will be transferred to the insurance company which is the risk of default, so that the premium costs are the responsibility of the lender and later the lender will be the beneficiary/beneficiary of the premium he paid.

4. Premium payments that have been made by lenders will later be distributed to insurance companies by the P2P Lending organizers. P2P Lending Operators as policy holders.

5. If in the future there is a default by borrower, where borrower is late in returning loan principal for more than 90 days. P2P Lending company will immediately pay insurance claim funds to lender after receiving payment from the insurance provider, refund guarantee varies from 70$100 \%$ of arrears of borrower's loan principal that is still owed until 90th day from due date. Claim period is 91 days (according to calendar) after loan due date.

6. For loans that have been insured, once claim is paid, right to collect loan is transferred to insurance company, this is where principle of subrogation in insurance applies. Insurance company will try to collect up to a number of claims paid. If the billing result is higher than claims paid, difference will be paid to lender (however this condition varies on each P2P Lending platform)

The designation of this insurance scheme completely avoids purpose of borrower loans for consumptive debt and prioritizes productive debts because dangers borne by insurance, dangers or events that are dependent on insurance must be stated clearly and unequivocally. If it is agreed with a clause, it must be clear with what clause, so that it is clear to what extent the liability of insurer is. Insurance party is only responsible for hazards that have been listed on the policy (Investree: 2020).

In financing distribution agreement between lender and organizer, it is stated that "loss guaranteed in this agreement is loss of financing recipient, financing recipient is unable to pay off its financial obligations as stated in the agreement between financing recipient and financier represented by provider on maturity date" so that when borrower has problems in paying installments 4 (four) times in a row and borrower is not included in tenor extension, then within 90 days after due date, P2P Lending platform will automatically process claim to insurance company. Insurance company will pay claim as soon as 6 weeks to 12 weeks after claim is submitted by P2P Lending party. A form of default that is not covered by insurance if borrower fails to pay due to force majeure such as a national natural disaster and war or 


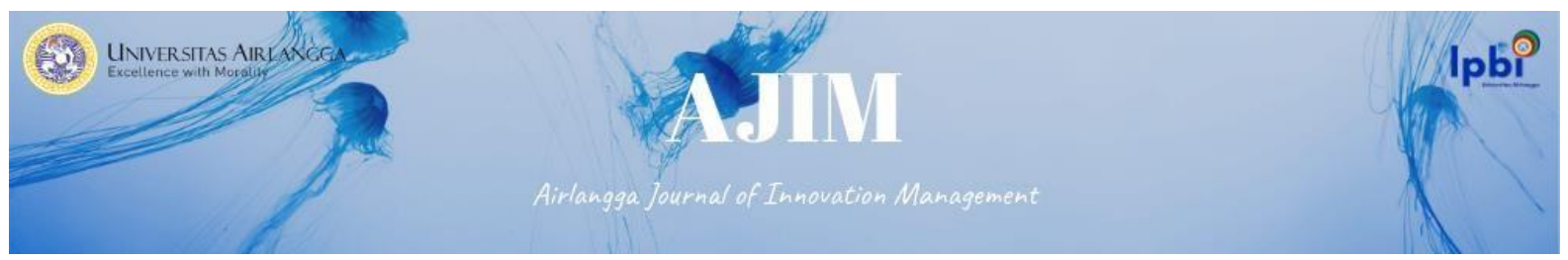

an emergency unless otherwise stipulated by a Regional Regulation or a Presidential Decree issued specifically to instruct insurance company to pay claim for risk of force majeure that occurred (Amartha: 2020).

Based on definition of privilege contract which states that an agreement is only valid between parties who make it. In this case lender only enters into an agreement with organizer where all rights and obligations of lender are stated from prohibition to insurance, there is no legal relationship between lender and insurance company because there is no agreement between two parties. Based on Article 284 of KUHD which states "if insurer has paid compensation to insured, insurer will replace insured's position on rights insured has obtained from a third party that has caused loss, and insured is responsible for actions that can eliminate any rights of insurer on a third party.Article $1400 \mathrm{BW}$ also states that "subrogation is replacement of debtor's rights by a third party, who pays debtor, occurs either by agreement or by law." So, in event of a default, insurance company protects loss suffered by insured and when insurer exercises its right of subrogation, insurer has right to replace lender's position as a creditor so that subrogation that occurs in legal construction is a subrogation that was born for sake of law. This is in line with intent of principle of idemnity (principle of balance) which implies that insurance is not for profit, so subrogation is needed to overcome this. In addition, legal position of insurance company is limited to covering lender's losses in event of a default and does not create an accessor agreement such as a cessie.

So it is hoped that use of insurance schemes in P2P lending services can be best solution for lenders' unpredictable losses even though existence of this insurance does not affect NPL percentage level of P2P Lending companies when there is a default because they will still be recorded as bad loans.

\section{Conclusion}

P2P Lending is a form of investment that also carries same risk as other types of investment, and this risk is directly proportional to return obtained (high risk high return). Risk of default can be caused by a recession/economic crisis, borrower's business goes bankrupt, borrower is laid off, P2P Lending company goes bankrupt, existence of cyber crime or overmarcht. Percentage of default in Indonesia, based on data from OJK in P2P Lending services in Indonesia is at 7.58\% as of October 2020. This value has increased when compared to previous period, so risk mitigation is indeed important as stipulated in Article 21 of POJK. No. 77/POJK.01/2016 which states that Operators and Users must carry out risk mitigation.

Risk mitigation plays an important role in increasing public interest and trust in investing in $\mathrm{P} 2 \mathrm{P}$ Lending. Purpose of insurance scheme in this P2P Lending fintech service is an effort to overcome uncertainty of losses experienced by lenders. In this case, lender pays premium through P2P Lending platform and then pays it to insurance company and then if there is a default lender receives insurance claim funds so that insurance scheme in P2P Lending can be said to be an effective method as risk mitigation against defaults that are likely to be experienced by lenders.

\section{References}

Abdila, Reynas. 2019. "OJK Usul P2P Lending Pakai Layanan Asuransi, Ini Alasannya", https://www.google.com/amp/s/m.tribunnews.com/amp/bisnis/2019 /02/22/ojk-usul-p2plending- pakai-layanan-asuransi-ini-alasannya.

Anugerah, D. P., \& Indriani, M. (2018, July). Data Protection in financial technology services: Indonesian legal perspective. In IOP Conference Series: Earth and Environmental Science (Vol. 175, No. 1, p. 012188). IOP Publishing.

Burgerlijk Wetboek (BW), Staatblad Tahun 1847 Nomor 23.

Bahsan M. 2007. "Hukum jaminan dan Jaminan Kredit Perbankan Indonesia”.Jakarta: Raja Grafindo Persada. 


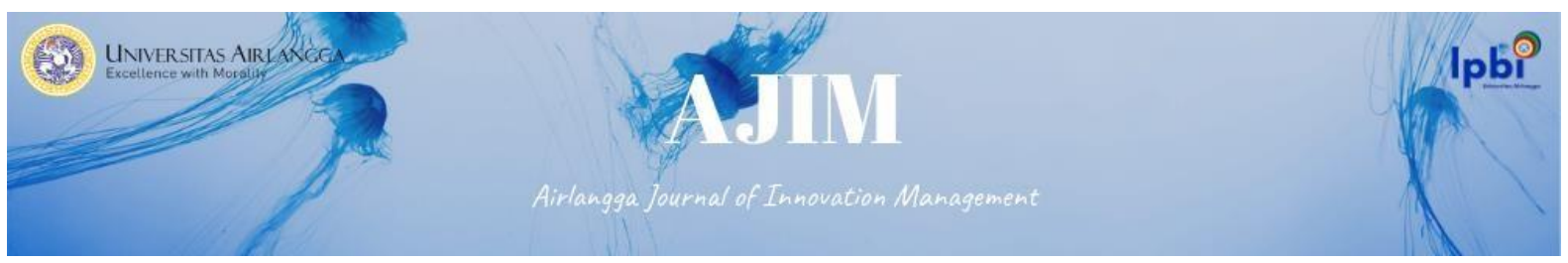

Bank Indonesia. 2020. "Apa yang dimaksud dengan Financial Technology" https://www.bi.go.id/id/edukasi-perlindungan-konsumen/edukasi/produk-dan-jasasp/fintech/Pages/default.aspx

Cermati.com. 2020. "Mengenal Lembaga Penjamin Simpanan, Apa Tugas dan Fungsinya?", https://www.google.com/amp/s/www.cermati.com/artikel/amp/men genal lembagapenjamin- simpanan-apa-tugas-dan-fungsinya.

Cindy Mutia Annur, "Pengembalian Pinjaman 90 Hari Fintech Lending Naik per

2020”, https://databoks.katadata.co.id/datapublish/2020/11/02/pengembalia

90-hari-fintech-lending-naik-per-september-2020\#

September

n-pinjaman-

Chumaida, Zahry Vandawati. "Perjanjian Asuransi Pertanian Pada Program Ketahanan Pangan Oleh Pemerintah”, Jurnal Hukum \& Pembangunan Universitas Indonesia.

Darman. 2019. "Financial Technology (Fintech): Karakteristik dan Kualitas Pinjaman pada Peer to Peer Lending di Indonesia”, Jurnal Manajemen Teknologi, Vol.18, No.2, 2019.

Fintech-Lending- Periode-Desember- 2019.aspx.

Franedya, Roy. 2020. "Inikah Bukti Warga RI Cuekin Bank, Pindah ke Fintech Lending?",, https://www.cnbcindonesia.com/tech/20200219125104-37- 138984/inikah-bukti-warga-ri-

cuekin-bank-pindah-ke-fintech-lending.

Hamzah, Andi. 1986. “Kamus Hukum”, Jakarta: Ghalia Indonesia, ,hlm. 425.

Harun B. 2010 “Penyelesaian Sengketa Kredit Bermasalah”, Yogyakarta: Pustaka Yustisia

Hartono, Sri Rejeki. 1995. "Hukum Asuransi dan Perusahaan Asuransi”, Jakarta: Sinar Grafika

Iman, Nofie. 2016. "Financial Technology dan Lembaga keuangan”, Gathering Mitra Linkage Bank

Syariah Mandiri, Yogyakarta,

Investree, "Pertanyaan Yang Sering Ditanyakan" https://investree.id/invest/faq

Investree, "Keunggulan Menjadi Borrower di Invetree”, https://investree.id/loan/

Kitab Undang-Undang Hukum Dagang (Wetboek van Koophandel voor Indonesie).

Kredit Gogo, "Kredit Tanpa Agunan Penyebab Kredit Macet dan Penyelesaiannya", https://kreditgogo.com/artikel/Kredit-Tanpa-Agunan/Penyebab- Kredit-Macet-danPenyelesaiannya.html.

Kristiyanti, Celina Tri Siwi .2008. "Hukum Perlindungan Konsumen”, Jakarata: Sinar Grafika

Marzuki, Peter Mahmud. 2017. "Penelitian Hukum: Edisi Revisi”, Jakarta: Prenada Media

Madian, Andri. 2020. "Mengalami Gagal Bayar di P2P Lending? Cek Beberapa Hal Ini Dulu", https://www.google.com/amp/s/www.akseleran.co.id/blog/gagal-bayar-p2p-lending-cekdulu/amp/

Mentari. 2020. “Seluk Beluk Peer to Peer (p2p) Lending “ ، $\quad$ https://financer.com/id/tabunganinvestasi/peer-to-peer-lending.

Otoritas Jasa Keuangan, "Statistik Fintech Lending Periode Desember 2019" https://www.ojk.go.id/id/kanal/iknb/data-dan- statistik/fintech/Pages/Statistik

Peraturan Menteri Komunikasi dan Informatika Republik Indonesia Nomor 112018 Tentang Penyelenggaraan Sertifikasi Elektronik Peraturan Bank Indonesia Nomor 19/12/PBI/2017 Tentang Penyelenggaran Teknologi Finansial.

Peraturan Otoritas Jasa Keuangan Nomor 1/POJK.05/2015 tentang Penerapan Manajemen Risiko bagi Lembaga Jasa Keuangan Non-Bank.Peraturan Otoritas Jasa Keuangan Nomor 77/POJK.01/2016 tentang Layanan Pinjam Meminjam Uang Berbasis Teknologi Informasi.

Peraturan Otoritas Jasa Keuangan Nomor 58/POJK.05/2020 tentang Perubahan Atas Peraturan Otoritas Jasa Keuangan Nomor 14/POJK.05/2020 tentang Kebijakan Countercyclical Dampak 


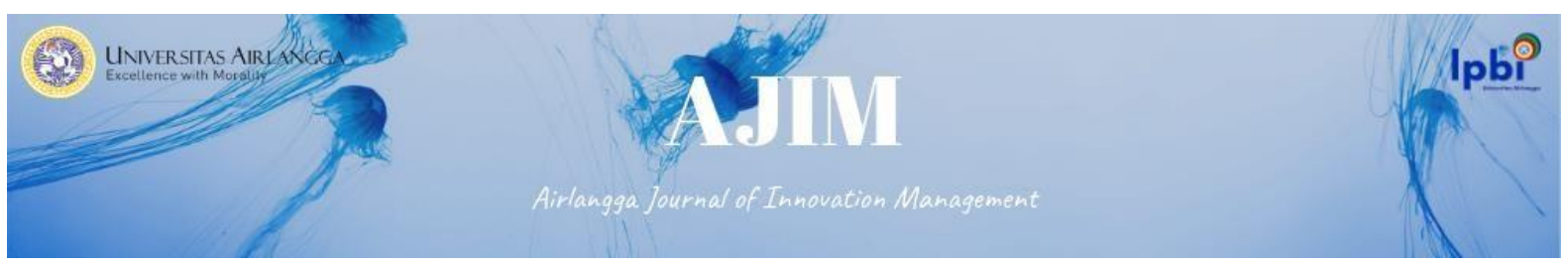

Penyebaran Coronavirus Disease 2019 bagi Lembaga Jasa Keuangan Nonbank.

Quiserto, R. 2019. "Resiko Investasi P2P Terlambat Dibayar (Pengalaman Di Koinworks \& Investree)", https://duwitmu.com/investasi/resiko-investasi-p2p- terlambat.

Undang-Undang Nomor 40 Tahun 2014 Tentang Perasuransian

Undang-Undang Nomor 19 Tahun 2016 tentang Perubahan atas Undang- Undang Nomor 11 Tahun 2008 tentang Informasi dan Transaksi Elektronik.

Walfajri, Maizal. 2020. "Pinjaman Macet P2P Lending di Level 7,58\% per Oktober”, OJK: Masih bisa dikendalikanhttps://keuangan.kontan.co.id/news/pinjaman- macet-p2p-lending-di-level- $\quad 758$ per-oktober-ojk-masih-bisa- dikendalikan, 2020. 